\title{
Agronomic Response of Aromatic Rice (Oryza sativa L.) as Influenced by Soil Textures and Water Levels
}

\author{
Ulysses A. Cagasan $^{1 \star}$, Carmenchita M. Tumaca ${ }^{2}$ and Purisima P. Juico ${ }^{3}$
}

\begin{abstract}
In crop production, it is essential to know the soil characteristics, water requirement, and crop suitability in order to have favorable plant growth and yield. This study was conducted to determine the growth and yield performance of aromatic rice grown in different soil textures and water levels. The experiment was laid out in a 2 × 3 split-plot, Completely Randomized Design (CRD) with three replications. Four containers per treatment $(21.5 \mathrm{~cm}$ and a height of $23 \mathrm{~cm}$ pail size) were used, each filled with $10 \mathrm{~kg}$ soil under saturated conditions. The different soil textures (S1-Clay Loam, S2- Clay) were designated as the main plots, and various water levels $(\mathrm{W} 1-1.5 \mathrm{~cm}, \mathrm{~W} 2-3.0 \mathrm{~cm}, \mathrm{~W} 3-5.0 \mathrm{~cm})$ were considered as the subplots. The results revealed that rice grown in clay loam soil (S1) were taller, had broader leaf area index, produced flower early, and have more number of tillers hill- ${ }^{1}(21.11)$. Likewise, longer panicle length $(21.79 \mathrm{~cm})$, highest percent filled grains $(82 \%)$, and total grain yield ( $\left.55 \mathrm{~g} \mathrm{hill-}{ }^{1}\right)$ equivalent to 6.11 t ha- $^{-1}$ were obtained from plants grown in clay loam soil. Plants grown in $3.0 \mathrm{~cm}$ water levels produced more productive tillers hill- ${ }^{-}$(21.83), the highest number of filled grains (138), and highest grain yield at $54.35 \mathrm{~g}$ hill- ${ }^{1}$ or equivalent to 5.99 t ha- $^{1}$.
\end{abstract}

Keywords: soil textures, aromatic rice, growth, productivity

\section{INTRODUCTION}

Aromatic rice constitutes a small but genetically distinct subpopulation within Asian cultivated rice (Roy et al 2020). Its desirability has resulted in strong human preference and selection for aromatic grains during domestication. Aromatic rice is commonly grown in irrigated lowland areas, especially in plain ecosystems. One of the research priorities in the Philippines is to produce rice that are not only high yielding, but also has good eating and aromatic quality. The aroma in rice grains is one of the most highly valued grain quality traits. These rice varieties have vast export potential because it is preferred in Arab countries such as Saudi Arabia, Kuwait, and Qatar, and Asian countries like the Philippines and Thailand (Ratilla and Cagasan 2011). It is also one of the significant rice types consumed by many

\footnotetext{
'Department of Agronomy, Visayas State University, Visca, Baybay City, Leyte, Philippines

${ }^{2}$ Department of Plant Science, Aklan State University, Banga, Aklan, Philippines

${ }^{3}$ Department of Soil Science, Central Luzon State University, Science of City Muñoz, Nueva Ecija, Philippines

*Corresponding Author : Address: Department of Agronomy, Visayas State University, Visca, Baybay City, Leyte, Philippines. E-mail: ulycagasan@vsu.edu.ph
} 
Filipinos (Zhao et al 2010). This particular rice variety has medium to long grains and is known for its nut-like aroma and taste, caused by the chemical compound called 2-Acetyl-1 Pyrroline (2AP). The types of aromatic rice include pandan, basmati, jasmine, and wild pecan rice. When cooked, the grains of these varieties have a light and fluffy texture.

The demand for rice is expected to keep increasing in the coming decades due to the growing population. About $75 \%$ of the global rice volume is produced in the irrigated lowlands. However, drought is one of the main constraints in getting high rice yields both in the lowland and upland conditions. Therefore, there is a need to maximize water use to increase rice productivity (Zhang et al 2012). Likewise, Ofori et al (2019) reported that by 2025, irrigated rice fields in Asia are expected to experience "physical scarcity" of water. Decreasing water availability for agriculture threatens the productivity of the irrigated rice ecosystem. Thus, new methods or irrigation options are urgently needed to save water and produce optimum crop yield.

According to Cagasan and Tamayo (2019), intermittent flooding that keeps the soil saturated provides better water-use efficiency and reduces water use up to $35 \%$ without affecting lowland rice yield. Alternate wetting and drying (AWD) have been reported to reduce water use up to $32 \%$ and increase yield to $15 \%$ (Escasinas and Zamora, 2011).

Soil management is another crucial cultural management practice to consider in rice production. However, in reality, soil management is the last factor considered in crop production. Nowadays, researchers are considering soil fertility as an essential aspect. Therefore, it is necessary to characterize the soil's physical and chemical properties before planting. Aside from this, cultural management practices on water and fertilizer use efficiency should also be appropriately integrated and considered. The capacity of the soil to hold moisture determines the efficiency of the plants to absorb nutrients. Thus, knowing the soil's physical characteristics, such as texture, structure, porosity, and bulk density, would help the overall crop production (Faylon et al 2007).

This study was conducted to determine the growth and yield performance of aromatic rice as influenced by soil textures and water levels and to identify the best treatment recommended for aromatic rice production.

\section{MATERIALS AND METHODS}

Thirty-six (36) black pails with a diameter of $21.5 \mathrm{~cm}$ and a height of $23 \mathrm{~cm}$ were used as pots in the experiment. Another 36 empty water containers ( 6 li cap) and 1.5 $\mathrm{m}$ wide $\mathrm{x} 10.0 \mathrm{~m}$ long plastic acetate for roofing were prepared. Two hundred (200) $\mathrm{kg}$ soil types (clay and clay loam), identified using the feel method, were randomly collected (at a depth of $0-20 \mathrm{~cm}$ ) using a shovel from the rice field. The soils were pulverized and properly sieved (cleared of debris and gravel). Water was drained, leaving only the clean soil, and placed in the pails. Ten (10) $\mathrm{kg}$ of soil in submerged conditions was used in this study. These were left submerged for five days before planting the rice seedlings. 
This study deals with soil textures and water levels, thus, a shed using light materials such as bamboo and plastic acetate was provided to control rainwater entry into the treatment pots. The shed was constructed to cover an area of $2.0 \mathrm{~m} \mathrm{x}$ $3.0 \mathrm{~m}$. The 36 pots were placed under the shed with $50 \mathrm{~cm}$ alleyways between pots for data gathering, water application, and other cultural management for rice.

A separate three hundred (300) grams soil sample was collected from each soil texture (clay and clay loam). These were air-dried until they could easily be pulverized and sieved. Fresh soil samples $(50 \mathrm{~g})$ were collected and oven-dried to determine the percentage (\%) MC of the fresh soil. Particle size distribution, or the percentage of clay, silt, sand, and actual soil texture, was determined using the pipette method. Chemical analysis was done on the two (2) soil textures to determine their nutrient content. The following tests were also conducted: for soil pH determination, 1:5 soil; $\mathrm{H}_{2} \mathrm{O}$ ISRIC 1995; for organic matter (OM) determination, the Modified Walkley-Black Method; for total Nitrogen (N), the Modified Kjeldahl; for available P, the Bray No. 2 Method; and for exchangeable K, the ammonium acetate method (with pH 7.0 for extraction and quantified using Varian 220 FS Atomic Absorption Spectrophotometer).

Moreover, exchangeable $\mathrm{K}$ and CEC were analyzed at the Bureau of Soils and Water Management (BSWM), Quezon City. Exchangeable cations ( $\mathrm{Ca}$ and $\mathrm{Mg}$ ) and the rest of the chemical analyses were done in the Soil Laboratory of the Department of Soil Science, College of Agriculture, Central Luzon State University, Science City of Munoz, Nueva Ecija. Soil textural class and chemical characteristics of soil used in the study were analyzed to determine the soil textures, condition, and nutrient content before the experiment was done (Tables 1 to 2).

The experiment was laid out in a $2 \times 3$ split-plot CRD with three replications. The different soil textures were designated as the main plot and the different water levels as the sub-plot. Replications were separated by $0.5 \mathrm{~m}$ alleyways between the treatment pots. Pot size (pail size $25 \mathrm{~cm} \times 35 \mathrm{~cm}$ ) and the treatments for the different soil textures: $\mathrm{S}_{1}$ - clay loam and $\mathrm{S}_{2}$-clay, served as the main plot. The different water levels: $W_{1} .1 .5 \mathrm{~cm}, W_{2} .3 .0 \mathrm{~cm}$, and $W_{3} .5 .0 \mathrm{~cm}$, served as the sub-plot. A twenty (20) day old seedlings of pandan aromatic rice (NSIC Rc216 variety) were taken from the Rice Research Area of CLSU, Science City of Munoz, Nueva Ecija. These were transplanted at two seedlings hill ${ }^{-1}$ in each treatment pot. Replanting of weak seedlings was done five days after transplanting. The fertilizer application rate used in the study was based on the result of the soil test kit (STK) equivalent to 120-60-60 kg ha ${ }^{-1} \mathrm{~N}, \mathrm{P}_{2} \mathrm{O}_{5}$, and $\mathrm{K}_{2} \mathrm{O}$.

Complete (14-14-14) fertilizer was prepared and applied five days after planting at $60-60-60 \mathrm{~kg} \mathrm{~N}, \mathrm{P}_{2} \mathrm{O}_{5}$, and $\mathrm{K}_{2} \mathrm{O} \mathrm{ha}^{-1}$ (6.43g hill ${ }^{-1}$ ), and the remaining $60 \mathrm{~kg} \mathrm{~N}$ was

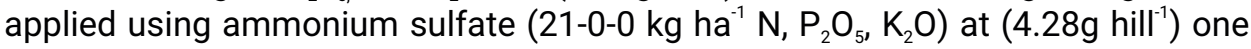
month after planting. The amount of water provided in the study was based on the water level required per treatment. Sticks were used to serve as markers on the treatments' water levels. Thus, water was checked every day to maintain the levels of water required per treatment. Moreover, the supply of water was stopped two weeks before harvesting to speed up the rice grains' maturity and firmness.

No chemical application was made. Hand weeding was done to remove weeds and handpicking was employed to control insect pests during the crop's vegetative, reproductive, and ripening stages. Moreover, during the reproductive phase, the rice 
plants were covered with nets to protect them from damaging pests such as rice rats (Oryzomys palutriz L.), Maya (Lonchura mallaca L.), and Gordon (Passer montanus L.).

Harvesting was done using a sharp sickle when $85 \%$ of the panicles in each treatment pot had ripened as indicated by amber-colored grains' firmness. All the productive panicles within the treatment pots were removed and used as samples for the yield parameters. Some data for the yield and yield components were gathered before the grains were sundried. Sun-drying to $14 \%$ moisture content was done before collecting the data on weight $(\mathrm{g})$ of 1,000 grains and total grain yield $\left(\right.$ ghill $\left.^{-1}\right)$. The parameters evaluated were soil chemical properties and agronomic characteristics such as number of days from sowing to $100 \%$ flowering, number of days from sowing to maturity, plant height $(\mathrm{cm})$, and number of tillers hill $^{-1}$. Likewise, yield and yield components were gathered, such as the number of productive tillers hill ${ }^{-1}$, the number of grains panicle ${ }^{-1}$, percent filled grains panicle ${ }^{-1}$, the weight of 1,000 grains $(\mathrm{g})$, and total grain yield $\left(\mathrm{g} \mathrm{hill}^{-1}\right)$.

The analysis of variance (ANOVA) was done using the Statistical Tool for Agricultural Research (STAR) version 1.0. The mean comparison was made using the Honestly Significant Difference (HSD) test at a $5 \%$ level of significance.

\section{RESULTS AND DISCUSSION}

Five (5) days after planting, complete (14-14-14) fertilizer was applied to the crop at a rate of $6.43 \mathrm{~g} \mathrm{hill}^{-1}$ or equivalent to $60-60-60 \mathrm{~kg} \mathrm{ha}^{-1} \mathrm{~N}, \mathrm{P}_{2} \mathrm{O}_{5}, \mathrm{~K}_{2} \mathrm{O}$. One (1) month after planting, vigorous growth with good tillering was observed in all treatment plants. However, yellowing of the leaves in some treatment plants, specifically on clay loam soil, was observed. Thus, a second fertilizer application was done using ammonium sulfate (21-0-0) at $4.28 \mathrm{~g} \mathrm{hill}^{-1}$ or equivalent to $60 \mathrm{~kg} \mathrm{ha}^{-1}$ $\mathrm{N}, \mathrm{P}_{2} \mathrm{O}_{5}, \mathrm{~K}_{2} \mathrm{O}$ in all treatment plots. Proper cultural management was done in all treatment plants, from planting up to harvesting.

\section{Soil Physico-chemical Characteristics}

Some of the physico-chemical characteristics of the soil used are presented in Tables 1 and 2. The soil texture, which was initially determined using the feel method, was revalidated in the laboratory following the Pipette method. The results revealed that the textural classification conducted in the laboratory conformed to the results generated in the field through the feel method, as shown in Table 1. 
Table 1. Textural classification of soil used in the study

\begin{tabular}{|c|c|c|c|}
\hline Soil Texture (Type) & $\begin{array}{c}\text { Soil Particles } \\
(\%)\end{array}$ & Soil Texture (Type) & $\begin{array}{c}\text { Soil Particles } \\
(\%)\end{array}$ \\
\hline $\mathrm{C}_{1}$ - Clay Loam & $\begin{array}{l}\text { Clay-36.49 } \\
\text { Silt- } 46.03 \\
\text { Sand-27.38 }\end{array}$ & $\mathrm{C}_{2}$-Clay & $\begin{array}{l}\text { Clay- } 58.04 \\
\text { Silt- } 31.70 \\
\text { Cand-10.26 }\end{array}$ \\
\hline
\end{tabular}

Table 2. Chemical characteristics of soil used in the study

\begin{tabular}{|c|c|c|c|c|c|c|c|c|}
\hline Soil Textures & $\mathrm{pH}$ & $\% \mathrm{OM}$ & $\% \mathrm{~N}$ & $\mathrm{P}(\mathrm{ppm})$ & $\begin{array}{c}\mathrm{K} \\
\left(\mathrm{cmol}^{(+)}\right) \\
\mathrm{kg}^{-1} \text { soil }\end{array}$ & $\begin{array}{c}\text { CEC } \\
\left(\mathrm{cmol}^{(+)}\right) \\
\mathrm{kg}^{-1} \text { soil }\end{array}$ & $\begin{array}{c}\mathrm{Ca} \\
\left(\mathrm{cmol}^{-1}\right. \\
(+) \mathrm{kg}^{-1} \\
\text { soil }\end{array}$ & $\begin{array}{c}\mathrm{Mg} \\
\left(\mathrm{cmol}^{-1}(+)\right. \\
\mathrm{kg}^{-1} \text { soil }\end{array}$ \\
\hline $\mathrm{S}_{1}$-Clay Loam & 5.18 & 0.61 & 0.06 & 7.12 & 3.72 & 82.93 & 4.03 & 0.50 \\
\hline $\mathrm{S}_{2}$-Clay & 4.67 & 0.12 & 0.03 & 2.45 & 3.42 & 36.06 & 2.12 & 0.42 \\
\hline
\end{tabular}

The soil organic matter (SOM), which reflects the soil's biological activity or property, varies in the two soil textures used in the study. The clay loam type had a value of 0.12 percent, while the clay type had 0.61 percent. Typically, a healthy soil has an average SOM value of $5 \%$, which means that the two soil types have low SOM content. The higher the SOM value, the better the biological activities occurring in the soil (Magdoff 2004). The soil pH of both clay loam and clay were considered strongly acidic. To some extent, soil pH influences nutrient availability for plant absorption and biological activity for nutrient mineralization (Dora Neina 2019). Most crops' pH range requirement is between 5.5 to 6.5 which is relative to nutrient availability for plant absorption. The pH of both soils used in the study is below 5.5 . However, for lowland submerged rice production, soil pH is not much of a problem because under submerged or reduced soil conditions, the soil $\mathrm{pH}$ increases until it reaches the equilibrium point (Kreyey 2009). As reflected by the cation exchange capacity (CEC), the soil test values showed a low to medium fertility level. As far as available nutrients are concerned, total $\mathrm{N}$ is low to medium, $\mathrm{P}$ is low, while exchangeable $\mathrm{K}, \mathrm{Ca}$, and $\mathrm{Mg}$ are high as far as rice production requirement is concerned. CEC is a measure of negatively charged sites on the surface which help in holding positively charged ions and nutrients such as sodium $(\mathrm{Na})$, potassium $(\mathrm{K})$, calcium (Ca), magnesium (Mg), and Zn (Liang et al 2006). The high CEC in clay loam soil could be attributed to the increase in soil $\mathrm{pH}$ value. Soils with low CEC become acidic very quickly, as observed in clay soil (Brown and Lemon 2016).

\section{Agronomic Characteristics}

The agronomic characteristics of pandan aromatic rice under different soil types are presented in Figure 1. 


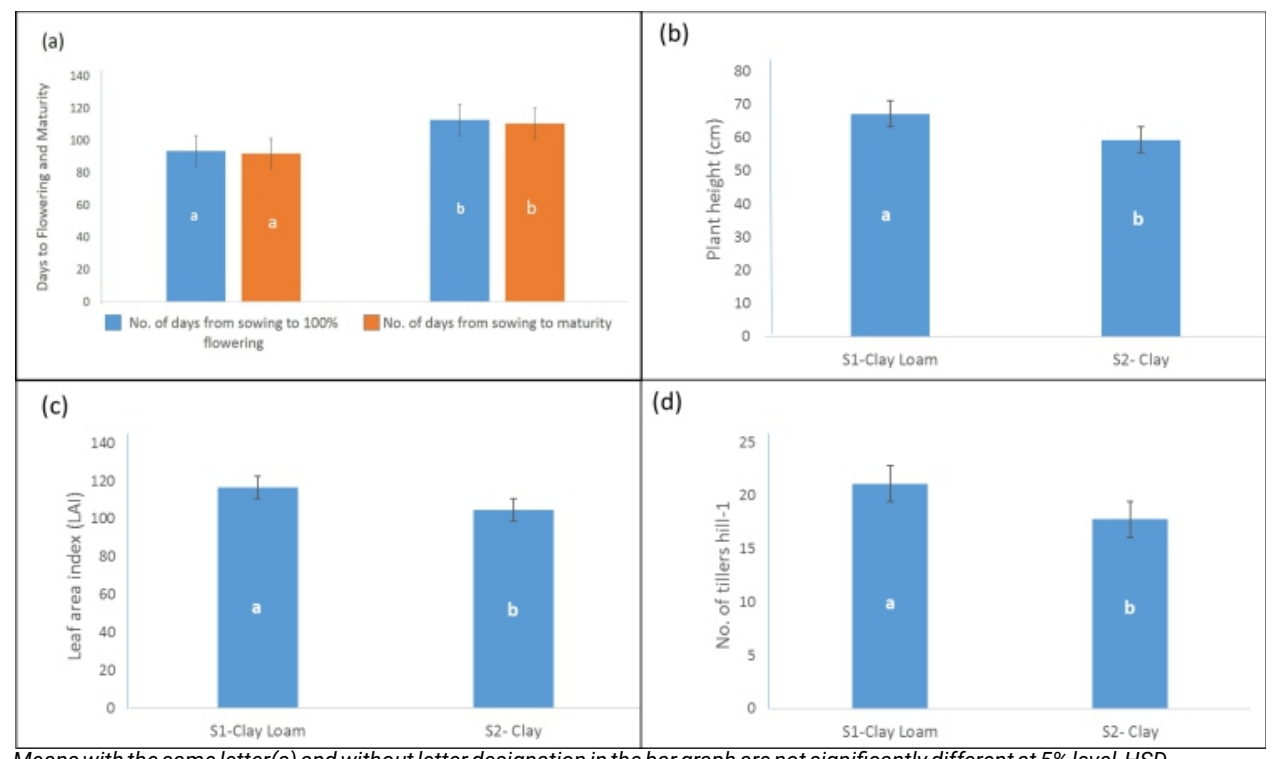

Means with the same letter(s) and without letter designation in the bar graph are not significantly different at $5 \%$ level, HSD.

Figure 1. (a) Days to flowering and maturity, (b) Plant height (cm), (c) Leaf Area Index, and (d) Number of tillers hill ${ }^{-1}$ of pandan aromatic rice as influenced by soil textures

The results revealed that rice plants grown on clay loam soil flowered late but had greater plant height $(\mathrm{cm})$, broader leaf area index, and produced more tillers hill 1. This result can be attributed to the characteristics of clay loam soil. Its particle size can behave like loamy soil if it has a healthy, fine, and friable soil texture, low soil $\mathrm{pH}$, high values of SOM content, \% N, amount of $\mathrm{P}, \mathrm{CEC}$ and $\mathrm{Ca}\left(\mathrm{cmol}(+) \mathrm{kg}^{-1}\right.$ soil (Table 2). These increased the agronomic and yield component parameters of pandan aromatic rice. This soil is also considered ideal for agricultural purposes because it retains nutrients and water while still allowing excess moisture to drain away, thus controlling the flow of water and nutrients distributed to the plant's different parts (Lindbo et al 2012). On the other hand, the clay soil used in this study was highly acidic (4.7) with low \% OM (Table 2). According to Bradl (2004), in acidic soil, the quantity of dissolved organic carbon is reduced, which reduces the availability of nutrients to the plants. These soil conditions could result in the early flowering of the rice plants, shorter plant height $(\mathrm{cm})$, smaller leaf area index, and fewer tillers hill ${ }^{-1}$. These results conformed to the study of Jayakumar (2005), which found that limited nutrients affected the plants' physiological process and resulted in the production of smaller leaves, early flowering, and shorter plant height.

On the other hand, the effects of water levels on pandan aromatic rice's agronomic characteristics are presented in Figure 2. The results showed that plant height $(\mathrm{cm})$ and leaf area index of the Pandan Aromatic rice (NSIC Rc216 variety) were significantly $(p<0.05)$ affected by the different water levels. The limited amount of water or the systems of rice intensification (SRI) method applied to the plants caused the shorter plant height $(\mathrm{cm})$ and smaller leaf area index. These 
results were similar to those of the study of some farmers in India. They observed that using less water enables rice to grow and produce flowers earlier than rice plants always submerged in water (Liu et al 2013).

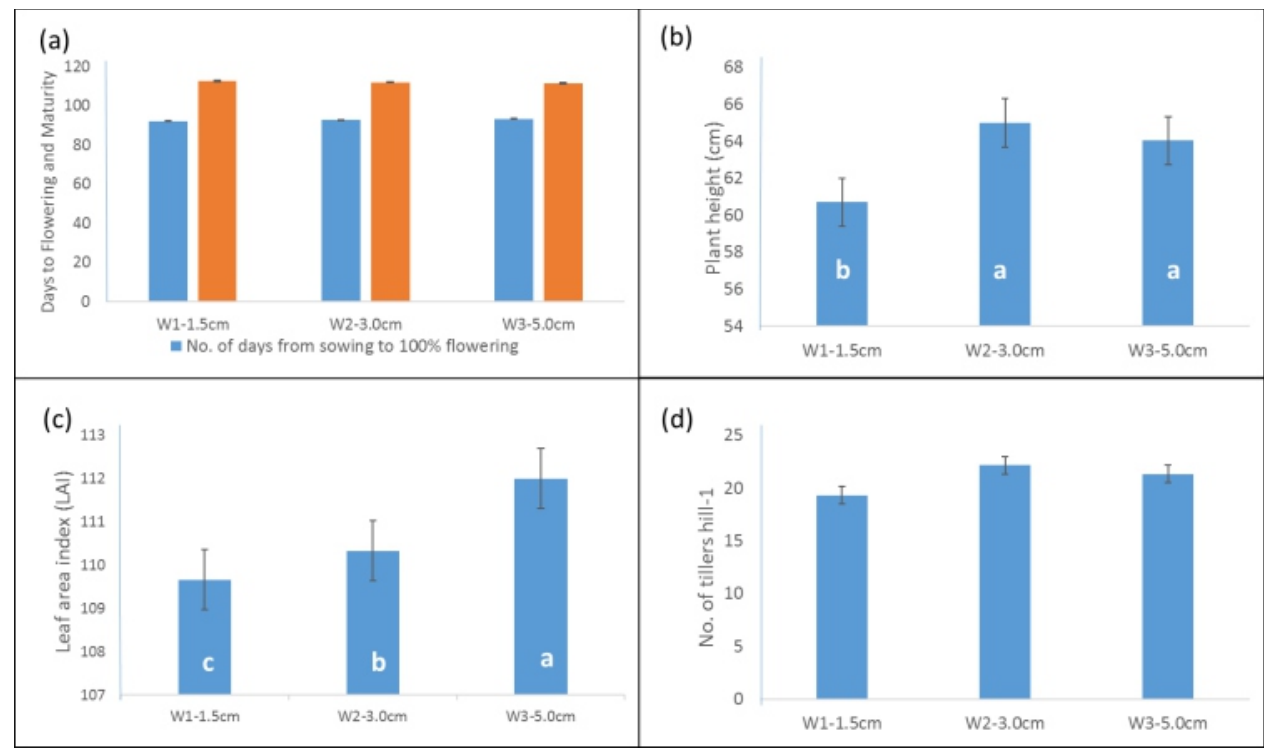

Means with the same letter(s) and without letter designation in the bar graph are not significantly different at $5 \%$ level, HSD.

Figure 2. (a) Days to $100 \%$ flowering and maturity, (b) Plant height (cm), (c) Leaf Area Index, (d) Number of tillers hill ${ }^{-1}$ of pandan aromatic rice as influenced by water levels

Rice plants grow taller with a broader leaf area index when grown in more water level $(5.0 \mathrm{~cm})$ than in lesser $(1.5-3.0 \mathrm{~cm})$. Moreover, Zhang et al (2012) believed that these rice intensification systems or SRI methods are new ways of cultivating rice and raising hopes that the rice yield would increase without threatening the country of water scarcity. On the other hand, the number of days from sowing to maturity and the number of tillers ${ }^{-1}$ did not significantly vary when the rice plants were grown in different water levels.

\section{Yield and Yield Components}

The yield and yield components of aromatic pandan rice grown in two soil textures are presented in Figure 3. Among the parameters evaluated, the number of productive tillers, panicle length $(\mathrm{cm})$, and total grain yield $\left(\mathrm{g}\right.$ hill $\left.{ }^{-1}\right)$ of aromatic pandan rice significantly $(p<0.05)$ increased when the rice plants were grown on clay loam soil. These results can be attributed to the higher CEC content in clay loam soil than in clay soil, indicating that the former is more fertile than the latter (Table 2). Clay loam soil has a better structure than clay soil. This means that clay loam soil has more available water for plants and better oxygen movement and gas exchange within the soil medium, thus increasing root growth and rooting depth to absorb nutrients. Conversely, clay soil can hold moisture but this can have difficulty 
passing through its aggregation. Thus, more water is retained and there is less oxygen in the soil environment. These cause problems in the plant's root development and water and nutrient absorption. In effect, plants' demands are not met particularly during grain development, thus affecting the rice plants' total grain yield. These results show that clay loam soil provides a more favorable condition for growing rice. This soil is characterized by medium texture with good porosity and soil aeration (Kaufmann and Cleveland 2008). In effect, this led to the increase in tillers' production and consequently resulted in high total grain yield ( $\left.\mathrm{g} \mathrm{hill}{ }^{-1}\right)$. This result confirms the reports of Gerhard (2017) that rice planted on soils with clay loam texture had significantly high rice grain yields. Moreover, he observed further that, grain yield of rice planted on clay loam soil was $26 \%$ higher than those on clay soil.

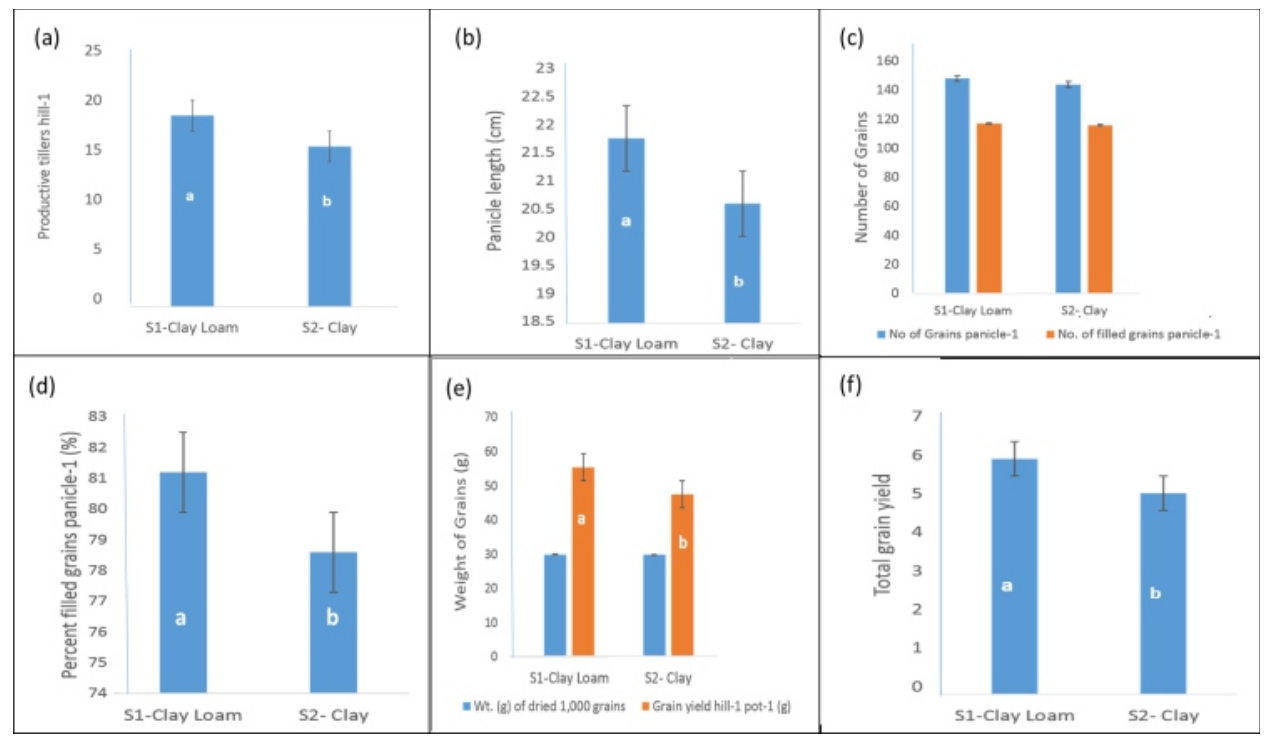

Figure 3. (a) Productive tillers hill-1, (b) Panicle length, (c) Number of grains, (d) \% filled grains ${ }^{-1},(\mathrm{e})$ Weight of grains $(\mathrm{g}),(\mathrm{f})$ Total grain yield $\left(\right.$ ghill $^{-1}$ ) of pandan aromatic rice as influenced by soil textures

On the other hand, the number of productive tillers hill ${ }^{-1}$, panicle length $(\mathrm{cm})$, number of grains, number of filled grains, percent (\%) filled grains panicle ${ }^{-1}$, the weight of 1,000 grains, and total grain yield ( $\mathrm{g} \mathrm{hill}^{-1}$ and $\mathrm{t} \mathrm{ha}^{-1}$ ) of rice plants are presented in Figure 4. The results show that productive tillers hill $^{-1}$ and the number of filled grains panicle ${ }^{-1}$ significantly $(p<0.05)$ increased when grown under $3.0 \mathrm{~cm}$ water level $\left(T_{2}\right)$. Moreover, the least number of tillers and filled grains were found in plants grown under $1.5 \mathrm{~cm}$ water level. These results were comparable to the plants grown in $5.0 \mathrm{~cm}$ water level. This condition resulted in the lower total grain yield. This further confirmed the findings of Jayakumar et al (2009) that the yield of rice in saturated conditions did not differ significantly to those in submerged conditions. 


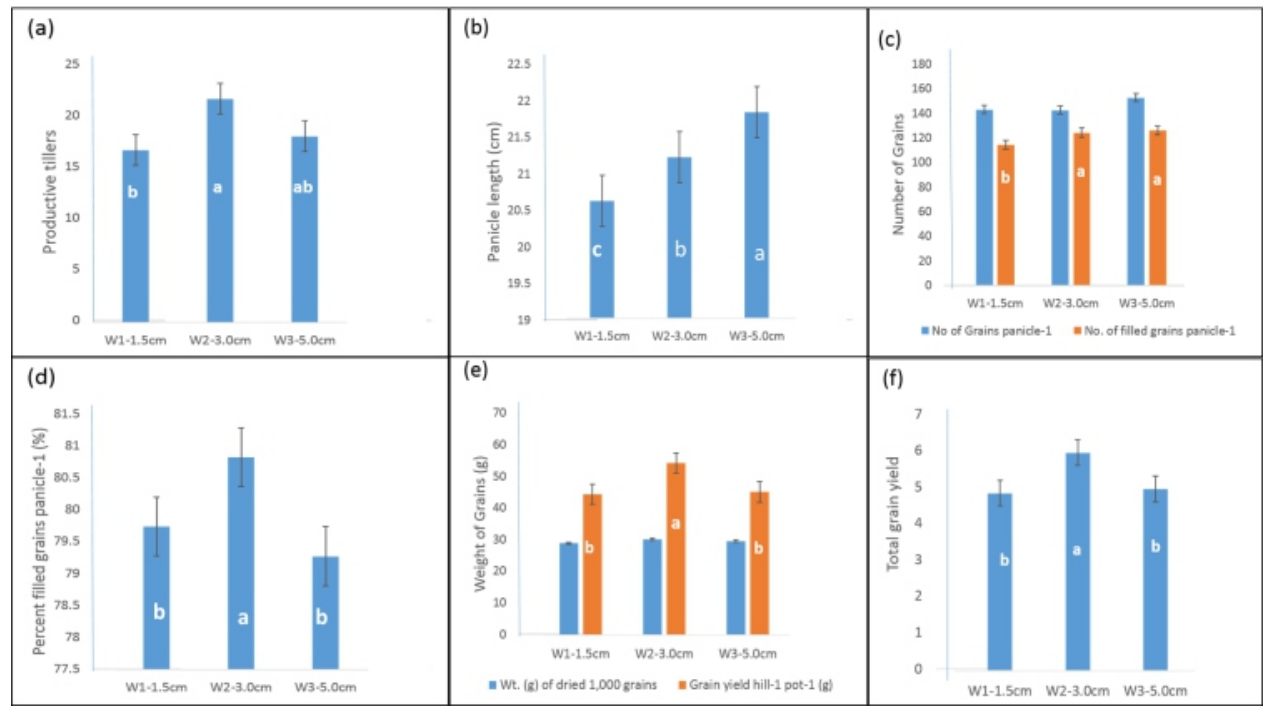

Means with the same letter(s) and without letter designation in the bar graph are not significantly different at $5 \%$ level, HSD.

Figure 4. (a) Productive tillers hill ${ }^{-1}$, (b) Panicle length, (c) Number of grains, (d) \% Filled grains ${ }^{-1}$, (e) Weight of grains and grain yield $\left(\mathrm{g}\right.$ hill $\left.{ }^{-1}\right),(\mathrm{f})$ Total grain yield ( $\mathrm{t}$ $\left.\mathrm{ha}^{-1}\right)$ of pandan aromatic rice as influenced by water levels

Moreover, research findings revealed that growing rice by maintaining a wet soil or saturated condition (without flooding) from transplanting to maturity is more productive than the conventional flooding system where the rice plants are always submerged in water (Jahan et al 2013a; Jahan et al 2014). This result can be attributed to the findings that root activity, as well as the gas exchange within the water and soil medium, is severely reduced under submerged conditions (Lerner 2017).

\section{CONCLUSION AND RECOMMENDATION}

Based on the results of the study, it was found that the number of days from sowing to flowering, plant height $(\mathrm{cm})$, leaf area index $(\mathrm{LAI})$, and the number of tillers hill ${ }^{-1}$ were significantly higher in rice planted on clay loam soil than those planted on clay soil. Pandan aromatic rice produced flowers earlier with larger LAI when grown in $3.0 \mathrm{~cm}$ water levels under the pot experiment. Moreover, plants grown on clay loam soil with $3.0 \mathrm{~cm}$ water level produced early flowers, had more productive tillers, and the heaviest filled grains panicle ${ }^{-1}$. Thus, these resulted in a higher grain yield of $54.35 \mathrm{~g} \mathrm{hill}^{-1}$ or equivalent to 5.99 tha $^{-1}$.

It is recommended that a similar study be conducted in the open field using the standard plot size to further evaluate the effects of the different soil textures and water levels (flooded and unflooded conditions) on the growth and yield of lowland pandan aromatic rice. A sensory evaluation should be included to assess the effect of soil texture and water levels on the aroma and taste of pandan rice. 


\section{REFERENCES}

Bradl HB. 2004. Adsorption of heavy metal ions on soils and soils constituents. Journal of Colloid and Interface Science, vol. 277(1), 1-18.

Cagasan UA, and Tamayo NV. 2019. Yield and physicochemical properties of lowland rice (Oryza sativa L. var. NSIC Rc218) as influenced by water and fertilizer applications. Int. J. Agric. for. Life Sci., 3(2), 264-269.

Escasinas RO and Zamora OB. 2011. Agronomic Response of Lowland Rice PSB Rc18 (Oryza sativa L.) to Different Water, Spacing, and Nutrient Management. Philippine Journal of Crop Science (PJCS) April 2011, 36 (1),37-46.

Faylon PS and Cardona EC. 2007. Philippine Agriculture: Retrospect and Prospects in Good Agricultural Practices Amid Globalization. Los Baños, Laguna, Philippines: Philippine Council for Agriculture, Forestry and Natural Resources Research and Development (PCARRD)

Gerhard K. 2017. Loam Construction from a niche product to an industrial building system. The 2005 World Sustainable Building Conference in Tokyo, Japan, September 2005

Jahan MS, Nozulaidi MBN, Khairi MB, CL, Khanif YM. 2013. Effects of water stress on rice production: bioavailability of potassium in soil. $J$ Stress Physio Biochem. 9:97-107.

Jahan MS, Nozulaidi MBN, Moneruzzaman MK, Ainun A, Husna N. 2014. Control of plant growth and water loss by a lack of light-harvesting complexes in photosystem-Il in Arabidopsis thaliana ch1-1 mutant. Acta Physiol Plant. 36: 1627-1635.

Jayakumar B, Subathra C, Velu V, and Ramanathan S. 2005. Effect of integrated crop management practices on rice (Oryza sativa L.) root volume and rhizosphere redox potential. Agronomy Journal, 4:311-314.

Kaufmann RK and Cleveland CJ. 2008. Environmental Science. McGraw-Hill.

Lindbo H and Adewunmi D. 2012. Know Soil Know Life: Physical Properties of Soil and Soil Formation. Soil Science Society of America. p. 17.

Liu M, Lin S, Dannenmann M, Tao Y, Saiz G, \& Zuo Q. 2013. Do water-saving through ground cover increase grain yields at regional scales? Field Crops Res 150:19-28

Ofori JV and Anning DK. 2019. The response of Lowland Rice (Oryza sativa L.) to Water Saving Management in the Coastal Savannah Agroecology of Ghana. West African Journal of Applied Ecology, 27(1), 127-136

Ratilla MD and Cagasan UA. 2011. Growth and yield performance of selected lowland rice varieties under alternate wet and dry water management. Annals of Tropical Research, 29:3-5

Rosie Lerner B. 2017, March 5. "What is Loam?", Purdue University. Consumer Horticulture.

Roy S, Banerjee A, Basak N, Kumar J \& Mandal NP. 2020. Aromatic Rice. In: Costa de Oliveira A., Pegoraro C., Ebeling Viana V. (eds) The Future of Rice Demand: 
Quality Beyond Productivity. Springer, Cham. https://doi.org/10.1007/978-3-030-37510-2_11

Turner BL. 2010. Variation in pH optima of hydrolytic enzyme activities in tropical rain forest soils. Applied and Environmental Microbiology, 76(19), 6485-6493.

Zhang X, Dai Q, Hu X, Zhu D, Ding X, \& Ma K. 2012. Effects of slow-release urea combined with conventional urea on rice output and growth in soils of different textures. Acta Agron Sinica,38:1494-1503.

Zhao, DL, Atlin, GN, Amante, M, Cruz, MT, \& Kumar A. 2010. Developing aerobic rice cultivars for water-short irrigated and drought-prone rainfed areas in the tropics. Crop Sci., 50:2268-2276. 